\title{
ANALISIS KOMPARATIF USAHATANI KENTANG ATLANTIK DAN KENTANG GRANOLA DI KECAMATAN SEMPOL
}

\section{COMPARATIVE ANALYSIS OF ATLANTIC POTATO AND GRANOLA POTATOES IN SEMPOL SUB-DISTRICT}

\author{
Tiyas Anggraeni Juiwati ${ }^{1}$, Henik Prayuginingsih ${ }^{2}$ dan Saptya Prawitasari ${ }^{2}$ \\ 1) Mahasiswa Program Studi Agribisnis, Fakultas Pertanian, UM Jember \\ 2) Dosen Program Studi Agribisnis, Fakultas Pertanian, UM Jember \\ e-mail: tiyasanggraini23@gmail.com
}

\begin{abstract}
ABSTRAK
Kentang merupakan tanaman sayuran unggulan yang memiliki potensi untuk berkembang di Indonesia, maka tujuan penelitian ini adalah : (1) Menganalisis perbedaan biaya produksi antara usahatani kentang atlantik dan kentang granola. (2) Menganalisis perbedaan keuntungan antara usahatani kentang atlantik dan kentang granola, dan (3) Mengidentifikasi faktor-faktor yang mempengaruhi produksi usahatani kentang. Data yang digunakan adalah data primer dan sekunder. Data yang terkumpul di analisis menggunakan uji-z dan Cobb-Dauglas. Berdasarkan hasil penelitian dapat di simpulkan : (1) Ada perbedaan biaya produksi antara usahatani kentang atlantik dan kentang granola namun secara statistik tidak berbeda nyata pada taraf kepercayaan $90 \%$. Biaya produksi kentang granola lebih tinggi yaitu sebesar Rp 22.500.279 sedang kentang atlantik lebih rendah yang sebesar Rp 22.146.941. (2) Ada perbedaan keuntungan antara usahatani kentang atlantik dan kentang granola, secara statistik berbeda nyata pada taraf kepercayaan 99\%. Keuntungan usahatani kentang granola lebih tinggi yaitu sebesar Rp 37.027.999/ha dibandingkan kentang atlantik yang sebesar Rp15.700.553/ha dan .(3) faktor-faktor yang berpengaruh dan signifikan terhadap produksi usahatani kentang adalah bibit, pupuk, tenaga kerja dan varietas, sedangkan faktor luas lahan dan pestisida berpengaruh positif tetapi secara statistik tidak signifikan terhadap produksi usahatani kentang di Kecamatan Sempol, Kabupaten Bondowoso.
\end{abstract}

Kata Kunci: Biaya, Keuntungan, Kentang

\section{ABSTRACT}

Potatoes are a superior vegetable plant that has the potential to develop in Potatoes are superior vegetable plants that have the potential to develop in Indonesia, so the objectives of this study are: (1) Analyzing the difference in production costs between farming Atlantic potatoes and Granola potatoes. (2) Analyzing the differences in profits between Atlantic potato farming and Granola potatoes, and (3) Identifying factors that influence potato farming production. The data used are primary and secondary data. The collected data was analyzed using the z-test and Cobb-Dauglas. Based on the results of the study it can be concluded: (1) There is a difference in production costs between Atlantic potato farming and Granola potatoes but statistically not significantly different from the $90 \%$ confidence level. The cost of producing granola potatoes is higher at Rp. 22,500,279 while atlantic potatoes are lower at Rp. 22,146,941. (2) There are differences in the advantages between Atlantic potato and Granola potato farming, statistically significantly different from the $99 \%$ confidence level. The advantages of granola potato farming are higher at Rp. 37,027,999 / ha compared to Atlantic potatoes which amount to 
Rp. 15,700,553 / ha and (3) factors that influence and significantly affect potato farming production are seeds, fertilizers, labor and varieties, while the land area and pesticide factors have a positive but not statistically significant effect on potato farming production in Sub Disctrict of Sempol, District of Bondowoso.

Keywords: Cost, Profit, Potatoes

\section{PENDAHULUAN}

Sektor pertanian merupakan sektor yang dapat diandalkan dalam pemulihan perekonomian nasional. Berbagai hal dapat dilakukan untuk mengembangkan pertanian sejak saat ini. Kesejahteraan petani dan keluarganya merupakan tujuan utama yang harus mejadi prioritas dalam melakukan semua kegiatan yang berhubungan dengan pengembangan pertanian (Anggriawan 2013). Namun menurut pendapat Soekartawi (1986) bahwa petani dengan segala keterbatasannya senantiasa dihadapkan pada ketidakpastian terhadap besarnya pendapatan yang diperoleh. Bagi para petani, khususnya petani subsisten, faktor ketidakpastian ini merupakan hal yang sangat berpengaruh dalam pengambilan keputusan. Pengelolaan usahatani pada hakekatnya merupakan langkah dalam pengambilan keputusan dari sekian alternatif yang tersedia. Pada umumnya petani di Indonesia belum mampu mengambil keputusan yang ekonomis menguntungkan. Hal ini mengingat pengelolaan usahatani bukan hanya mencakup cara menghasilkan produk yang maksimum, tetapi yang lebih penting adalah bagaimana mempertinggi keuntungan dari suatu cabang usaha. Hortikultura merupakan sub sektor potensial dari sektor pertanian yang mempunyai nilai ekonomi dan permintaan yang tinggi. Salah satu komoditas produk hortikultura yang menjadi unggulan adalah tanaman kentang (Solanum tuberosum L). Kentang merupakan salah satu pangan utama dunia setelah padi, gandum, dan jagung (Wattimena, 2000).

Kentang (Solanum tuberosum L) merupakan tanaman sayuran unggulan yang memiliki potensi untuk berkembang di Indonesia. Dari segi teknis, agribisnis komoditas kentang sudah cukup berkembang dan menyebar di sebagian besar daerah di Indonesia. Dari segi produktivitas dan mutu, komoditas kentang yang dikembangkan di Indonesia sudah tergolong cukup tinggi (Sihombing 2005). Banyaknya manfaat kentang membuat pengusahaan komoditi ini terus berkembang. Kentang sebagai bahan makanan untuk konsumsi manusia merupakan salah satu sumber nutrisi paling besar yang mengandung karbohidrat, zat besi, Vitamin B1, B2 dan 
Vitamin C. Kandungan lemak yang terdapat pada kentang lebih rendah dibandingkan dengan padi, jagung dan gandum. Kandungan gizi yang dimiliki oleh kentang ini telah menjadikan salah satu alternatif sumber karbohidrat nabati utama selain padi bagi masyarakat (Ashandi, 1995).

Rata-rata produksi kentang di Indonesia sebesar 1.116.524 ton per tahun dengan tingkat pertumbuhan
6,81\%. Pada tahun 2011 dan 2012 produksi kentang di Indonesia mencapai 955.488 ton dan 1.094.232 ton dengan tingkat pertumbuhan masing-masing sebesar $-9,93 \%$ dan $14,52 \%$. Setelah itu produksi kentang meningkat pada tahun 2013 dan 2014 yang masing-masing produksinya mencapai 1.374 .815 ton dengan perkembangan $19,88 \%$ di tahun 2013 mencapai 1.124.282 ton dengan perkembangan $2,75 \%$ (Gambar 1).

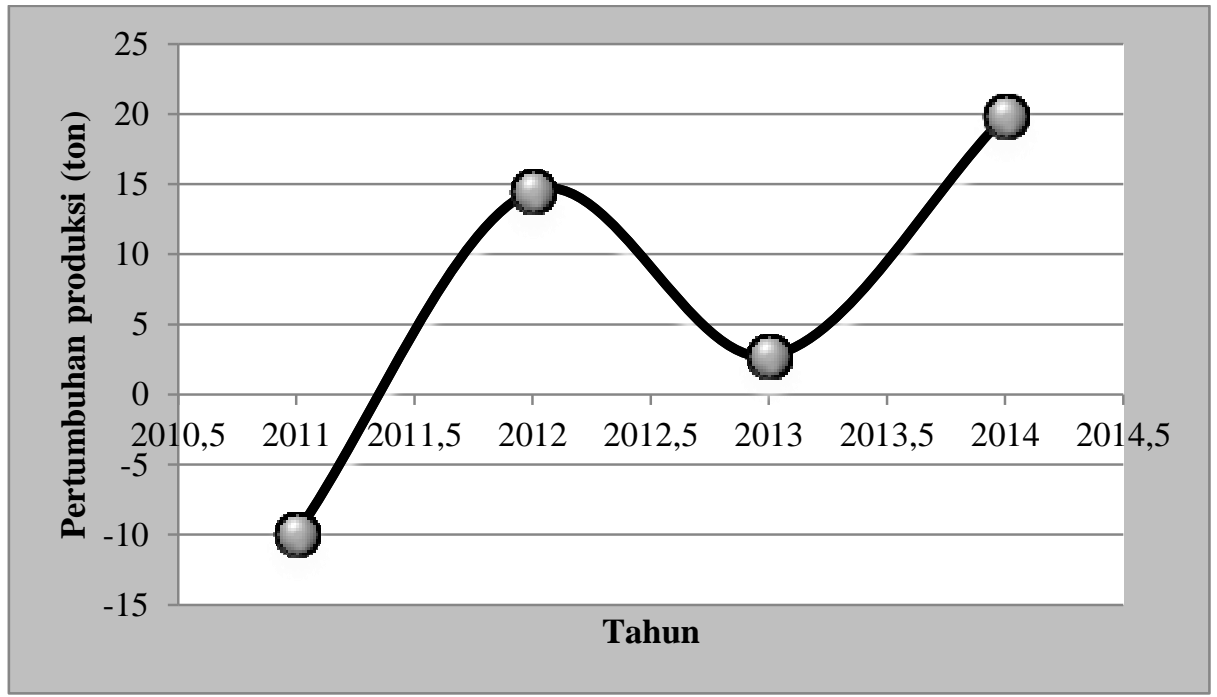

Gambar 1. Pertumbuhan Produksi Kentang di Indonesia

Tahun 2010-2014 (Sumber: Kementerian Pertanian Diolah, 2017).

Bondowoso merupakan salah satu pertumbuhan luas penan, produksi dan kabupaten di Jawa Timur yang produktivitas kentang di Bondowoso mengahsilkan kentang. Pada Tabel 1 Tahun 2010-2014.

memberikan informasi tentang

Tabel 1. Pertumbuhan Luas panen, Produksi dan Produktivitas Kentang Di Kabupaten Bondowoso Tahun 2010-2014

\begin{tabular}{cccccccc}
\hline No & Tahun & $\begin{array}{c}\text { Luas } \\
\text { Panen } \\
\text { (ha) }\end{array}$ & $\begin{array}{c}\text { Pertum- } \\
\text { buhan } \\
(\boldsymbol{\%})\end{array}$ & $\begin{array}{c}\text { Produksi } \\
\text { (ton) }\end{array}$ & $\begin{array}{c}\text { Pertum } \\
\text { buhan } \\
(\boldsymbol{\%})\end{array}$ & $\begin{array}{c}\text { Produkti- } \\
\text { vitas } \\
\text { (ton/ha) }\end{array}$ & $\begin{array}{c}\text { Pertum- } \\
\text { buhan } \\
(\%)\end{array}$ \\
\hline 1 & 2010 & 24 & - & 433 & - & 18,04 & - \\
2 & 2011 & 63 & 162,50 & 1.148 & 165,13 & 18,22 & 1,00 \\
3 & 2012 & 85 & 34,92 & 1.575 & 37,20 & 18,53 & 1,69 \\
4 & 2013 & 245 & 188,24 & 4.454 & 182,79 & 18,18 & $-1,89$ \\
5 & 2014 & 149 & $-39,18$ & 2.797 & $-37,20$ & 18,77 & 3,26 \\
\hline \multicolumn{2}{l}{ Rata-rata } & $\mathbf{1 1 3 , 2 0}$ & $\mathbf{8 6 , 6 2}$ & $\mathbf{2 . 0 8 1}$ & $\mathbf{8 6 , 9 8}$ & $\mathbf{1 8 , 3 5}$ & $\mathbf{1 , 0 1}$ \\
\hline
\end{tabular}

Sumber: BPS Bondowoso (diolah 2017). 
Pada Tabel 1 memperlihatkan luas panen kentang di Kabupaten Bondowoso pada tahun 2010-2014 rataratanya 113,20 ha. Luas panen ternyata berdampak pada produksi di Kabupaten Bondowoso. Rata-rata produksi kentang di Kabupaten Bondowoso selama periode 2010-2014 mengalami kenaikan sebesar $86,98 \%$. Demikian pula produktivitas juga mengalami fluktuasi, dimana pada tahun 2010-2014 rata-rata produktivitas kentang $1,01 \%$. Ada dua varietas kentang yang dikembangkan di Kecamatan Sempol, Kabupaten Bondowoso yaitu kentang atlantik dan kentang granola. Kentang granola merupakan jenis kentang sayur yang paling banyak dipakai dalam masakan Indonesia. Kentang granola memiliki bentuk lonjong dan daging kuning. Kandungan pati dalam kentang granola termasuk rendah dan kandungan airnya tinggi. Kentang ini cocok untuk dibuat sup dan perkedel, sedangkan kentang atlantik warna dagingnya agak terang, agak kasar ketika diraba. Kentang atlantik memiliki kandungan pati yang lebih tinggi dan kandungan air yang lebih rendah dari kentang granula, sehingga cocok untuk hidangan yang dioalah dengan cara digoreng atau dipanggang, misalnya French fries atau baked potato, perbedaan antara kedua varietas tersebut dilihat pada Tabel 2.

\section{Tabel 2. Kentang Atlantik dan Kentang Granola}

\begin{tabular}{clll}
\hline No & Perbedaan & \multicolumn{1}{c}{ Kentang Granola } & \multicolumn{1}{c}{ Kentang Atlantik } \\
\hline 1 & Harga jual & $\begin{array}{l}\text { Harga lebih tinggi karena mengikuti } \\
\text { harga pasar sedangkan }\end{array}$ & $\begin{array}{l}\text { Harga lebih rendah karena harga } \\
\text { jual ditentukan oleh perusahaan }\end{array}$ \\
\hline 2 & Hama & $\begin{array}{l}\text { Lebih tahan terhadap hama penyakit. } \\
\text { Lebih rentan terhadap hama } \\
\text { penyakit. }\end{array}$ \\
\hline 3 & Bibit & $\begin{array}{l}\text { Dapat menggunakan hasil seleksi } \\
\text { panen sebelumnya }\end{array}$ & $\begin{array}{l}\text { Tidak dapat menggunakan bibit } \\
\text { sebelumnya }\end{array}$ \\
\hline
\end{tabular}

Tabel 2 memaparkan perbedaan antara kentang granola dan kentang atlantik. Perbedaan terletak pada harga kentang granola yang lebih tinggi dibanding kentang atlantik. Kentang granola ini lebih tahan terhadap hama penyakit dibandingkan kentang atlantik, selain itu kentang granola dapat menggunakan hasil seleksi panen sebelumnya sedangkan kentang atlantik tidak dapat menggunakan bibit dengan hasil panen sebelumnya, berdasarkan hal tersebut diketahui perbedaan usahatani kentang granola dan kentang atlantik di Kecamatan Sempol ,Kabupaten Bondowoso ditinjau dari sisi ekonomi.

$$
\text { Penelitian usahatani kentang }
$$
atlantik di Kecamatan Gatesan, Kabupaten Semarang dapat diketahui bahwa biaya sarana produksi yang 
menyumbang biaya terbesar dalam musim tanam adalah dalam pembelian bibit yakni sebesar Rp 18.535.833/ha. Bibit diperoleh dengan cara impor. Petani memperoleh bibit dari PT Indofood Fritoly Makmur yang dibayar setelah panen. Harga bibit yang cukup mahal yakni Rp 13.000/kg mendorong petani untuk mencari cara mengefisiensikan penggunaan bibit. Cara yang dilakukan adalah membelah bibit menjadi dua bagian, setiap hasrus memiliki mata tunas. Rata-rata pendapatan petani kentang atlantik sebesar $\mathrm{Rp}$ 45.336.460/ha.

Pendapatan petani kentang atlantik tergolong tinggi mengingat dengan perawatan kentang atlantik yang cikup beresiko dikarenakan kentang atlantik sangat rentan terhadap OPT yang dapat mengurangi hasil produksi dan dapat pula menyebabkan gagal panen ( Oktaviana 2014). Selanjutnya hasil penelitian Maulia (2012) menyimpulkan bahwa perbedaan hasil pendapatan usahatani kentang antara varietas atlantik dan granola yang dilakukan petani responden di Desa Cigedug secara umum menguntungkan dan layak untuk diusahakan. Hal ini dapat ditunjukkan dari pendapatan rata-rata atas biaya total yang diusahakan responden varietas granola adalah Rp 33.256.875,51/ha dan varietas atlantik $\mathrm{Rp}$ 42.206.449,23/ha.
Oleh karena itu perlu dilakukan suatu penelitian yang mengkaji tentang keuntungan, biaya produksi, dan faktorfaktor yang berpengaruh pada produksi kedua jenis kentang tersebut di Kecamatan Sempol Kabupaten Bondowoso. Berdasarkan fakta ini, maka penelitian ini burtujuan: (1) Untuk menganalisis perbedaan biaya produksi antara usahatani kentang atlantik dan kentang granola; (2) Untuk menganalisis perbedaan keuntungan antara usahatani kentang atlantik dan kentang granola; dan (3) Untuk mengidentifikasi faktor-faktor yang mempengaruhi produksi usahatani kentang di Kecamatan Sempol, Kabupaten Bondowoso.

\section{METODOLOGI PENELITIAN}

\section{Metode Penelitian dan Penentuan Lokasi Penelitian}

Metode yang digunakan dalam penelitian ini adalah metode survey dan metode komparatif. Metode survey merupakan cara untuk mengumpulkan data dari sejumlah unit atau individu dalam jangka waktu tertentu secara bersamaan, metode survey juga melakukan wawancara secara langsung kepada petani atau responden. Daerah penelitian ditentukan secara purposive (sengaja) di enam Desa di Kecamatan Sempol yaitu di Desa Jampit, Desa 
Sempol, desa Kalisat, desa Kalianyar, Desa kaligedang dan Desa Sumberrejo.

\section{Metode Pengambilan Sampel}

Pemilihan dipergunakan metode purposive random sampling atau sengaja. Sebelum dilakukan responden tersebut telah dilakukan atau di tentukan jumlah sampel dari sejumlah populasi yang terdapat dilokasi sampel, adapun jumlah populasi di Desa Jampit 41 orang petani, Desa Sempol 31 orang petani, Desa Kalisat 23 orang petani, Desa Kalianyar 42 orang petani, Desa Kaligedang 33 orang petani dan Desa Sumberrejo 27 orang petani.

\section{Metode Pengumpulan Data}

Data yang digunakan dalam penelitian ini adalah data primer dan data sekunder. Data primer diperoleh melalui observasi langsung di lapangan dan wawancara langsung dengan petani. Data sekunder diperoleh melalui penelusuran berbagai dokumen dari literatur-literatur yang relevan seperti buku, majalah pertanian, jurnal ilmiah, internet, Dinas Pertanian, Badan Pusat Statistik (BPS) dan instansi terkait lainnya.

\section{Metode Analisis Data}

Metode analisis data yang digunakan untuk menjawab tujuan pertama dan kedua dilakukan pendekatan analisa biaya dan keuntungan. Selanjutnya guna mengetahui ada tidaknya perbedaan antara biaya dan keuntungan usahatani kedua jenis kentang tersebut digunakan uji-Z. Hipotesis yang diajukan adalah:

$\mathrm{H}_{0}$ : Tidak ada perbedaan rata-rata variabel yang diperbandingkan antara varietas kentang, atau $\mu_{1}=\mu_{2}$ atau $\mu_{1}-\mu_{2}=0$

$\mathrm{H}_{\mathrm{a}}$ : Ada perbedaan rata-rata variabel yang dibandingkan antar dua varietas kentang, $\mu_{1} \neq \mu_{2}$ atau $\mu_{1}-\mu_{2} \neq 0$

Kriteria pengambilan keputusan adalah:

a. Jika $Z_{\text {hitung }} \leq Z_{(\alpha / 2)}$, maka $H_{0}$ diterima dan $\mathrm{H}_{\mathrm{a}}$ ditolak

b. Jika $Z_{\text {hitung }}>Z_{(\alpha / 2)}$, maka $\mathrm{H}_{0}$ ditolak dan $\mathrm{H}_{\mathrm{a}}$ diterima

Jika $\mathrm{Z}$ hitung $\leq \mathrm{Z}$ tabel, maka dapat dinyatakan bahwa perbedaan rata-rata variabel yang dibandingkan antar dua varietas kentang secara statistik tidak signifikan. Akan tetapi, apabila terbukti bahwa $\mathrm{Z}$ hitung $>\mathrm{Z}$ tabel, maka dari uji$\mathrm{Z}$ tersebut dihasilkan kesimpulan antar dua vaietas kentang secara statistik signifikan.

Pengujian sampel menggunakan uji $\mathrm{Z}$ dengan rumus sebagai berikut (Supranto, 2009):

$$
z=\frac{\left(\bar{X}_{1}-\bar{X}_{2}\right)-\left(\mu_{1}-\mu_{2}\right)}{\sqrt{\frac{\sigma_{1}^{2}}{n_{1}}+\frac{\sigma_{2}^{2}}{n_{2}}}}
$$


di mana:

$\bar{X}_{1}$ dan $\bar{X}_{2}=$ nilai rata-rata dari variabel 1 dan -2 yang diamati

$\left(\mu_{1}-\mu_{2}\right)=$ perbedaan antara rata-rata populasi yang dihipotesiskan $\sigma_{1}^{2}$ dan $\sigma_{2}^{2}=$ varians dari populasi-1dan populasigresi dari faktor-faktor yang $n_{1}$ dan $n_{2}=$ ukuran dari sampel- 1 dan sampel- 2

di mana apabila $\sigma_{1}^{2}$ dan $\sigma_{2}^{2}$ tak diketahui, dapat diestimasi dengan:

$$
z=\frac{\left(\bar{X}_{1}-\bar{X}_{2}\right)-\left(\mu_{1}-\mu_{2}\right)}{\sqrt{\frac{s_{1}^{2}}{n_{1}}+\frac{s_{2}^{2}}{n_{2}}}}
$$

di mana:

$\bar{X}_{1}$ dan $\bar{X}_{2}=$ nilai rata - rata dari sampel-1 dan sampel- 2 yang diamati $\left(\mu_{1}-\mu_{2}\right)=$ perbedaan antara rata-rata populasi yang dihipotesiskan

$s_{1}^{2}$ dan $s_{2}^{2}=$ varians dari populasi- 1 dan populasi- 2 $n_{1}$ dan $n_{2}=$ ukuran dari sampel-1 dan sampel- 2

Selanjutnya untuk mengetahui faktor-faktor yang berpengaruh terhadap produksi usahatani kentang atlantik dan kentang granola, digunakan pendekatan analisis regresi berganda dengan asumsi bahwa bentuk hubungan antara variabel bebas $(\mathrm{X})$ dengan variabel terikat $(\mathrm{Y})$ merupakan fungsi produksi cobbDouglass. Hubungan antara variabel $\mathrm{X}$ dan $\mathrm{Y}$ tersebut secara matematik dirumuskan sebagai berikut (Sutiarso,2010):

Pengujian keberartian koefisien regresi secara keseluruhan (simultan).

$\mathrm{H}_{0}$ : Semua koefisien regresi dari faktorfaktor yang berpengaruh terhadap varriabel produksi tidak berbeda nyata berpengaruh terhadap variabel produksi berbeda nyata dengan nol, atau

dengan nol

$$
\beta_{1}=\beta_{2}=\ldots=\beta_{k}=0
$$

$\mathrm{H}_{\mathrm{a}}$ : Paling tidak salah satu koefisien

$$
\beta_{j}=0
$$

Pengujian hipotesis dilakukan secara statistik menggunakan uji $\mathrm{F}$ dengan formulasi sebagai berikut:

$$
F_{\text {hitung }}=\frac{\text { kuadrattengahregresi }}{\text { kuadrattengahsisa }}
$$

Jika $\left|F_{\text {hit }}\right|\left\{\begin{array}{l}\leq \mathrm{F}_{(\propto ; n-k-1)}, \text { maka } \mathrm{H}_{0} \text { diterima } \\ >\mathrm{F}_{(\propto ; \mathrm{n}-\mathrm{k}-1)}, \text { maka } \mathrm{H}_{0} \text { ditolak }\end{array}\right.$

di mana:

$\mathrm{n}=$ jumlah observasi

$\mathrm{k}=$ jumlah variabel bebas

Pengujian keberartian koefisien regresi parsial secara individual. Untuk faktor yang berpengaruh positif terhadap produksi, diajukan hipotesis sebagai berikut:

$\mathrm{H}_{0}$ : Koefisien regresi dari faktorfaktor yang berpengaruh terhadap variabel produksi tidak berbeda nyata atau sama dengan nol, atau $\beta_{\mathrm{j}}=0$

Ha: Koefisien regresi dari faktorfaktor yang berpengaruh terhadap variabel produksi 
lebih besar daripada nol, atau $\beta_{\mathrm{j}}>0$

Pengujian hipotesis dilakukan secara statistik dengan uji-t sebagai berikut:

$$
t_{\text {hitung }}=\frac{b_{i}-\beta_{j}^{*}}{s_{b j}}
$$

di mana $\beta_{\mathrm{j}}$ yang sesuai dengan hipotesis nol, dan $S_{b j}$ adalah standart error dari $b_{\mathrm{j}}$. Kriteria pengambilan keputusan:

Jika $\left|t_{\text {hit }}\right|\left\{\begin{array}{l}\leq \mathrm{t}_{(\propto ; \mathrm{n}-\mathrm{k}-1)}, \text { maka } \mathrm{H}_{0} \text { diterima } \\ >\mathrm{t}_{(\propto ; \mathrm{n}-\mathrm{k}-1)}, \text { maka } \mathrm{H}_{0} \text { ditolak }\end{array}\right.$

$$
\gamma=\beta_{0} X_{1}^{\beta_{1}} X_{2}^{\beta_{2}} \ldots X_{i}^{\beta_{i}} e^{\delta D+\varepsilon i}
$$

Faktor-faktor yang diduga mempengaruhi produksi usahatani kentang granola dan kentang atlantik adalah luas lahan, bibit, pupuk, pestisida, tenaga kerja dan varietas kentang. Secara matematik, persamaan taksiran fungsi produksi dengan model regresi adalah:

$\hat{Y}=b_{0} X_{1}^{b_{1}} X_{2}^{b_{2}} X_{3}^{b_{3}} X_{4}^{b_{4}} X_{5}^{b_{5}} X_{6}^{b_{6}} e^{d D+\varepsilon_{i}}$

Untuk memudahkan pendugaan persamaan tersebut di atas, maka persamaan tersebut diubah menjadi bentuk linier berganda dengan cara melogaritmakan. Persamaan regresi dinyatakan dalam bentuk persamaan logaritma dengan bilangan pokok e = 2,71828, sehingga persamaannya menjadi: $\ln Y_{i}=\ln \beta_{0}+\beta_{1} \ln X_{1 i}+\beta_{2} \ln X_{2 i}+\ldots+\beta_{k} \ln X_{k i}+{ }^{\delta} D \ln e+\ln \varepsilon_{i}$

\section{HASIL DAN PEMBAHASAN}

\section{Biaya Usahatani Kentang}

Biaya produksi adalah pengeluaran yang dilakukan selama proses produksi, meliputi seluruh pengeluaran untuk pembelian inputinput yang dipakai dalam suatu produksi, seperti biaya sarana produksi, biaya tenaga kerja dan biaya sewa lahan. Biaya sarana produksi adalah biaya yang terdiri dari biaya, bibit, pupuk, dan pestisida. Biaya tenaga kerja adalah biaya yang dikeluarkan untuk tenaga kerja selama proses produksi berlangsung. Biaya tetap adalah semua biaya yang dikeluarkan dan tidak habis dalam satu kali produksi untuk biaya sewa lahan. biaya variabel adalah biaya yang dikeluarkan untuk kebutuhan produksi yang habis dipakai dalam satu kali produksi terdiri dari biaya saprodi dan biaya tenaga kerja. Struktur biaya tetap dan biaya variabel usahatani kentang tersaji pada Tabel 6.2. 
Tabel 3.Struktur Biaya Usahatani Kentang per hektar di Kecamatan Sempol, Kabupaten Bondowoso Tahun 2017

\begin{tabular}{|c|c|c|c|c|c|c|}
\hline \multirow{2}{*}{ Jenis Biaya } & \multicolumn{2}{|c|}{ Kentang atlantik } & \multicolumn{2}{|c|}{ Kentang Gr Nilai anola } & \multirow[t]{2}{*}{ Rata-rata } & \multirow{2}{*}{$\begin{array}{l}\text { Nilai } \\
(\%)\end{array}$} \\
\hline & Nilai & $(\%)$ & & & & \\
\hline $\begin{array}{l}\text { 1) Biaya Tetap } \\
\text { - Sewa Lahan }\end{array}$ & 2.138 .333 & 9,66 & 1.736 .667 & 7,72 & 1.937 .500 & 8,68 \\
\hline 2) Biaya Variabel & & & & & & \\
\hline - Saprodi & & & & & & \\
\hline $\begin{array}{ll}\text { a. } & \text { Bibit } \\
\text { b. } & \text { Pupuk }\end{array}$ & 7.577 .170 & 34,21 & 8.188 .000 & 36,39 & 7.882 .585 & 35,311 \\
\hline I.Urea & 378.218 & 1,71 & 412.842 & 1,83 & 395.530 & 1,77 \\
\hline II.NPK & 283.211 & 1,28 & 282.575 & 1,26 & 282.893 & 1,26 \\
\hline III.SP36 & 500.766 & 2,26 & 569.197 & 2,53 & 534.982 & 2,39 \\
\hline IIII.Organik & 5.794 .343 & 26,16 & 5.968 .895 & 26,53 & 5.881 .619 & 26,34 \\
\hline c. Pestisida & & & & & & \\
\hline i. Furadon & 304.834 & 1,38 & 306.079 & 1,36 & 305.456 & 1,37 \\
\hline ii. Acrobat & 457.251 & 2,06 & 459.118 & 2,04 & 458.185 & 2,05 \\
\hline iii. Tiezene & 102.833 & 0,46 & 158.611 & 0,70 & 130.722 & 0,59 \\
\hline - Tenaga Kerja & & & & & & \\
\hline -Pengolahan Lahan & 206.511 & 0,93 & 235.020 & 1,04 & 220.765 & 0,99 \\
\hline -Pembuatan Gulutan & 577.123 & 2,61 & 653.174 & 2,90 & 615.148 & 2,76 \\
\hline -Penanaman & 437.040 & 1,97 & 477.009 & 2,12 & 457.025 & 2,05 \\
\hline -Pemupukan & 714.915 & 3,23 & 806.134 & 3,58 & 760.524 & 3,41 \\
\hline -Pengendalian Hama & 1.468 .185 & 6,63 & 1.051 .116 & 4,67 & 1.259 .650 & 5,64 \\
\hline -Pemangkasan Bunga & 293.804 & 1,33 & 270.938 & 1,20 & 282.371 & 1,26 \\
\hline -Penyiangan & 342.771 & 1,55 & 316.094 & 1,40 & 329.433 & 1,48 \\
\hline - Panen & 569.632 & 2,57 & 608.813 & 2,71 & 589.222 & 2,64 \\
\hline Jumlah & 20.008.608 & 90,34 & 20.763.613 & 92,28 & 20.386.110 & 91,32 \\
\hline Total Biaya & 22.146 .941 & 100 & 22.500 .279 & 100 & 22.323 .610 & 100 \\
\hline
\end{tabular}

Sumber : Analisis data primer (2017).

Tabel 3 menunjukkan bahwa biaya produksi total usahatani kentang atlantik Rp 22.146.941/ha, sebagian besar $(90,34 \%)$ atau sebesar Rp20.008.608/ha merupakan biaya variabel dan hanya sebagian kecil $(9,66 \%)$ atau $\mathrm{Rp} 2.138 .333 / \mathrm{ha}$ merupakan biaya tetap sewa lahan. Hal yang sama terjadi pada usahatani kentang granola. Biaya total sebesar Rp 22.500.279/ha, sebagian besar $(92,28 \%)$ atau sebesar 20.763.613 merupakan biaya variabel dan hanya sebagian kecil $(7,72 \%)$ atau sebesar Rp 1.736.667/ha merupakan biaya tetap. Rata-rata biaya total usahatani kentang Rp 22.323.610/ha, terdiri dari biaya variabel $(91,34 \%)$ atau sebesar Rp 20.386.110/ha dan hanya sebagian kecil biaya tetap $(8,68 \%)$ atau sebesar Rp 1.937.500/ha.

Biaya variabel kedua terbesar digunakan untuk pembelian bibit. Kentang atlantik sebesar Rp $7.557 .170 /$ ha $(34,21 \%)$ dan untuk granola sebesar $\mathrm{Rp}$ 8.811.000/ha $(36,39 \%)$ secara rata-rata sebesar $\mathrm{Rp}$ 7.882.585/ha $(35,11 \%)$, disusul biaya pupuk, biaya pupuk tertinggi adalah pupuk organik. Biaya pupuk organik pada kentang atlantik sebesar Rp 5.794.343/ha $(26,16 \%)$, sedangkan 
pada kentang granola sebesar $\mathrm{Rp}$ $5.881 .619 /$ ha $(26,53 \%)$ dan secara ratarata sebesar Rp 5.881.619/ha (26,34\%). Kondisi ini menunjukkan bahwa penggunaan pupuk organik pada usahatani kentang di Kecamatan Sempol Kabupaten Bondowoso sudah cukup bagus. Karena penggunannya lebih banyak dibanding pupuk kimia.

Biaya variabel terbesar ketiga adalah tenaga kerja. Pada kentang atlantik digunakan biaya sebesar $\mathrm{Rp}$ $1.468 .185 /$ ha $(6,63 \%)$ penggunaan tenaga kerja terbesar untuk upah penyemprotan pestisida sedangkan pada kentang granola sebesar Rp $1.259 .650 /$ ha $(5,64 \%)$ dan secara ratarata sebesar $\operatorname{Rp~1.259.650/ha~}(31,41 \%)$.
Pada umunya penyemprotan pestisida pada varietas atlantik dilakukan seminggu sekali sedangkan pada granola dua minggu sekali, tanpa menunggu ada serangan hama penyakit. Berdasarkan penggunaan biaya produksi pada kedua jenis kentang, bahwa kentang atlantik mengeluarkan biaya produksi yang lebih kecil dibanding dengan kentang granola, hal ini disebabkan karena biaya variabel yang dikeluarkan untuk usahatani kentang granola lebih besar. Perbedaan biaya produksi di antara kedua usahatani kentang berbeda namun tidak signifikan secara statistik pada taraf kepercayaan 90\% tersaji pada Tabel 4 .

Tabel 4. Rata-rata Perbedaan Biaya Usahatani Kentang Atlantik dan Kentang Granola di Kecamatan Sempol, Kabupaten Bondowoso Tahun 2017

\begin{tabular}{clcccc}
\hline No & $\begin{array}{c}\text { Jenis Usahatani } \\
\text { Kentang }\end{array}$ & Mean & $\begin{array}{c}\text { Z- } \\
\text { hitung }\end{array}$ & $\begin{array}{c}\text { Z- } \\
\text { tabel }\end{array}$ & $\begin{array}{c}\text { Probabilitas } \\
\text { Signifikan }\end{array}$ \\
\hline 1 & Atlantik & $22.146 .941,25$ & $-0,562$ & 1,960 & $0,574^{\mathrm{ns}}$ \\
2 & Granola & $22.500 .279,17$ & & & \\
\hline
\end{tabular}

Keterangan: ns: tidak signifikan pada taraf kepercayaan $90 \%$

Sumber: Analis data primer (2017

\section{Keuntungan Usahatani Kentang}

Harapan kegiatan usahatani adalah diperolehnya keuntungan yang maksimum. Besarnya keuntungan yang akan diterima petani tidak hanya ditentukan oleh tingginya produksi, akan tetapi juga ditentukan oleh harga jual dan besarnya biaya yang dikeluarkan. Hasil perkalian antara produksi dan harga menghasilkan penerimaan. Semakin tinggi tingkat penerimaan maka tingkat keuntungan semakin tinggi, dengan asumsi biaya produksi yang dikeluarkan dipertahankan tetap. Keuntungan yang tinggi juga dapat diperoleh apabila petani dapat menghemat biaya yang dikeluarkan, dengan asumsi tingkat 
penerimaan dipertahankan tetap. Ratarata tingkat keuntungan usahatani kentang di Kecamatan Sempol, Kabupaten Bondowoso dapat dilihat pada Tabel 5 .

Tabel 5 menunjukkan bahwa rata-rata produksi kentang alantik lebih kecil sebesar $9.462 \mathrm{~kg} / \mathrm{ha}$ dengan harga Rp 4.000/kg. Harga jual kentang atlantik merupakan hasil kesepakatan dengan PT Indofood. Produksi kentang granola lebih besar yaitu $9.666 \mathrm{~kg} / \mathrm{ha}$ dengan harga jual Rp 6.158/kg. Harga jual kentang granola lebih tinggi karena mengikuti harga pasar dan untuk saat ini harga jual kentang granola dipasar sedang stabil. Petani kentang atlantik bersedia menerima harga jual rendah karena memperoleh pinjaman modal terlebih dahulu dari PT Indofood. Pengembalian modal dilakukan pada saat panen dengan cara memotong dari hasil penjualan tanpa ada perhitungan bunga pinjaman. PT Indofood tidak menjalin kesepakaan dengan petani kentang granola karena yang dibutuhkan adalah kentang untuk pembuatan French fries atau baked potato sedang granola cocoknya untuk kentang sayur.

Tabel 5. Produksi, Biaya dan Keuntungan per hektar Usahatani Kentang di Kecematan Sempol, Kabupaten Bondowoso Tahun 2017

\begin{tabular}{|c|c|c|c|c|}
\hline \multirow{2}{*}{ No } & \multirow{2}{*}{ Uraian } & \multicolumn{2}{|c|}{ Usahatani Kentang } & \multirow{2}{*}{ Rata-rata } \\
\hline & & Atlantik & Granola & \\
\hline 1 & Produksi (kg) & 9.462 & 9.666 & 9.564 \\
\hline 2 & Harga (Rp/kg) & 4.000 & 6.158 & 5.079 \\
\hline 3 & Penerimaan (Rp/ha) & 37.847 .495 & 59.528 .278 & 48.687 .886 \\
\hline 4 & Biaya $(\mathrm{Rp} / \mathrm{ha})$ & 22.146 .941 & 22.500 .279 & 22.323 .610 \\
\hline 5 & Keuntungan (Rp/ha) & 15.700 .553 & 37.027 .999 & 26.364 .276 \\
\hline
\end{tabular}

Sumber: Analisis data primer (2017).

Pada kondisi produksi yang relatif sama namun harga jual yang jauh berbeda menyebabkan terjadinya perbedaan keuntungan antar varietas kentang. Usahatani kentang atlantik yang menerima harga lebih rendah menerima keuntungan yang lebih rendah pula. Rata-rata keuntungan yang diperoleh usahatani kentang atlantik lebih kecil yaitu sebesar
Rp15.700.553/ha dibandingkan dengan kentang granola dengan keuntungan yaitu sebesar Rp37.027.999/ha. Secara ekonomis kedua usahatani tersebuat dikatakan menguntungkan. Untuk mengetahui perbedaan keuntungan kentang berdasarkan jenisnya yang menggunakan uji-Z dua arah, tersaji pada Tabel 6. 
Tabel 6. Keuntungan per hektar Usahatani Kentang Atlantik dan Kentang Granola di Kecamatan Sempol, Kabupaten Bondowoso Tahun 2017

\begin{tabular}{clcccc}
\hline No & Jenis Usahatani Kentang & Mean & Z-hitung & Z-tabel & $\begin{array}{c}\text { Probabilitas } \\
\text { Signifikan }\end{array}$ \\
\hline 1 & Kentang Atlantik & 15.700 .553 & $-11,89$ & 1,95 & $0,00^{* * *}$ \\
2 & Kentang Granola & 37.027 .999 & & \\
\hline
\end{tabular}

Keterangan: Pengujian hipotesis menggunakan uji-z dua arah, di mana ${ }^{* * *}$ menyatakan signifikan kepercayaan $99 \%$.

Sumber: Analis data primer (2017).

Berdasarkan uji-z dua arah yang ditunjukkan pada Tebal 6.7 dapat diketahui bahwa perbandingan keuntungan usahatani kentang berdasarkan jenisnya menunjukkan adanya perbedaan yang signifikan pada taraf kepercayaan 99\%. Hasil penelitian menunjukkan bahwa sistem kemitraan yang terjadi antara petani kentang atlantik dengan PT Indofood mempunyai sisi positif dan negatif. Sisi positif mendapat pinjaman modal terlebih dahulu tanpa membayar bunga dan pengunaan biaya produksi lebih murah karena petani mendapat bimbingan teknis terlebih dahulu. Sisi negatifnya mendapat harga yang lebih murah dan produktivitas lebih rendah dengan luas tanam yang lebih besar.

\section{Faktor-faktor yang Berpengaruh Terhadap Produksi Usahatani Kentang}

Hasil akhir dari proses produksi adalah produk (output). Hubungan antara jumlah penggunan input dan jumlah output yang dihasilkan, dengan tingkat teknologi tertentu disebut fungsi produksi. Dalam usahatani kentang faktor-faktor yang diduga berpengaruh terhadap produksi berupa luas lahan, bibit, pupuk, pestisida, tenaga kerja, dan varietas kentang.

Tabel 7. Hasil Analisis Faktor yang Mempengaruhi Produksi Usahatani Kentang Tahun 2017

\begin{tabular}{|c|c|c|c|c|}
\hline Variabel & Parameter & Koefísien Regresi & & Sig \\
\hline Konstanta & $\beta_{n}$ & 1,759 & 3,900 & 0,000 \\
\hline Luas Lahan & $\beta_{1}$ & $0,142^{\mathrm{ns}}$ & 1,303 & 0,198 \\
\hline Bibit & $\beta_{2}$ & $0,348^{\cdots \pi}$ & 2,432 & 0,018 \\
\hline Pupuk & $\beta_{3}$ & $0,257^{\cdots \cdots}$ & 4,620 & 0,000 \\
\hline Pestisida & $\beta_{4}^{3}$ & $0,062^{\mathrm{ns}}$ & 0,558 & 0,579 \\
\hline Tenaga Kerja & $\beta_{5}$ & $0,157^{* * *}$ & 2,828 & 0,007 \\
\hline Rummv Varietas. & $\beta^{6}$ & $0,103^{* * *}$ & 4,129 & 0,000 \\
\hline $\begin{array}{l}\text { Std. Error Estimasi } \\
\text { S Square }\end{array}$ & $\begin{array}{l}S e \\
R^{2}\end{array}$ & $\begin{array}{l}0,077 \\
0,057\end{array}$ & & \\
\hline $\begin{array}{l}\text { Adjusted R Square } \\
\text { F-Hitung }\end{array}$ & $R^{L}$ & 0,947 & & \\
\hline
\end{tabular}

Keterangan: Pengujian hipotesis menggunakan uji-z dua arah, di mana ,**,*** menyatakan signifikan

masing-masing pada tingkat kepercayaan $, 95 \%, 99 \%$. ns:

signifikan $10 \%$.

Sumber: $\quad$ Analisis data primer (2017). 
Persamaan analisis regresi fungsi produksi rata-rata usatahani kentang atlantik dan kentang granula dapat dirumuskan:

$\operatorname{Ln} Y=1,759+0,142 \operatorname{Ln} X_{1}+0,348 \operatorname{Ln} X_{2}+0,257 \operatorname{Ln} X_{3}+0,062 \operatorname{Ln} X_{4}$ $+0,157 \operatorname{Ln} X_{5}+0,103 \ln e$

Kentang granola $\mathrm{D}=0$ :

$\operatorname{Ln} Y=1,759+0,142 \operatorname{Ln} X_{1}+0,348 \operatorname{Ln} X_{2}+0,257 \operatorname{Ln} X_{3}+0,062 \operatorname{Ln} X_{4}$ $+0,157 \operatorname{Ln} X_{5}$

Kentang atlantik $=1$ :

$\operatorname{Ln} Y=1,759+0,142 \operatorname{Ln} X_{1}+0,348 \operatorname{Ln} X_{2}+0,257 \operatorname{Ln} X_{3}+0,062 \operatorname{Ln} X_{4}$ $+0,157 \operatorname{Ln} X_{5}$

$\operatorname{Ln} Y=1,862+0,142 \operatorname{Ln} X_{1}+0,348 \operatorname{Ln} X_{2}+0,257 \operatorname{Ln} X_{3}+0,062 \operatorname{Ln} X_{4}$ $+0,157 \operatorname{Ln} X_{5}$

Secara matematik dapat

diformulasikan dengan fungsi produksi

rata-rata Cobb-Douglas sebagai berikut:

Pada kentang granola:

$Y=5,807 X_{1}^{0,142} X_{2}^{0,348} X_{3}^{0,257} X_{4}^{0,062} X_{5}^{0,157}$

Pada kentang atlantik:

$Y=6,437 X_{1}^{0,142} X_{2}^{0,348} X_{3}^{0,257} X_{4}^{0,062} X_{5}^{0,157}$

Faktor luas lahan, jumlah bibit, jumlah pupuk, jumlah pestisida, tenaga kerja dan varietas kentang secara bersama-sama berpengaruh signifikan terhadap nilai produksi usahatani kentang atlantik dan kentang granula. Hal ini dapat dilihat dari F-hitung $(=176,331)$ yang sangat signifikan pada tafar uji $1 \%$. Jika ditinjau dari nilai koefisien determunasi $\left(\mathrm{R}^{2}\right)$ yang sebesar 0,952 menunjukkan bahwa variabel bebas yang dimasukkan ke dalam model dapat mengidentifikasikan variasi variabel dependen (nilai produksi) secara baik sekitar 95,2\%. Hanya sekitar 5\% yang dijelaskan oleh faktor lain yang tidak masuk ke dalam model diantaranya adalah curah hujan dan iklim.

Apabila dilihat dari nilai koefisien regresi parsial dengan menggunakan fullmodel, maka faktor produksi luas lahan, jumlah bibit, jumlah pupuk, tenaga kerja dan varietas kentang secara bersama berpengaruh positif dan signifikan terhadap produksi kentang. Sementara pengaruh dari variabel luas lahan dan pestisida berpengaruh positif tetapi tidak signifikan. Maka secara parsial dapat dijelaskan pengaruh variabel bebas terhadap variabel terikat sebagaimana bahasan berikut.

Luas lahan mempunyai pengaruh yang positif akan tetapi secara statistik tidak signifikan pada taraf uji $10 \%$. Artinya, semakin luas lahan garapan usahatani kentang atlantik dan granola, semakin besar produksi yang diperolehnya. Nilai koefisien regresi menunjukkan bahwa suatu peningkatan luas lahan sebesar $1 \%$ akan mengakibatkan produksi petani meningkat sebesar $0,142 \%$ dengan asumsi cateris paribus. Variabel

bibit berpengaruh positif dan secara statistik signifikan pada taraf uji $5 \%$. Artinya, penggunaan bibit yang 
digunakan berpengaruh secara nyata terhadap produksi kentang. Nilai koefisien regresi sebesar 0,348 diartikan bahwa setiap penambahan jumlah bibit sebesar $1 \%$, maka produksi kentang akan meningkat sebesar $0,348 \%$.

Variabel pupuk berpengaruh positif, dan secara statistik signifikan pada taraf uji 1\%. Artinya, semakin banyak pupuk yang digunakan, maka semakin besar produksi yang diproleh. Nilai koefisien regresi sebesar 0,257 penggunaan pupuk sebesar $1 \%$ akan mampu meningkatkan produksi kentang sebesar $0,257 \%$. Variabel pestisida berpengaruh positif dan secara statistik tidak signifikan pada taraf uji $10 \%$. Artinya penggunaan pestisida tidak berpengaruh nyata terhadap produksi, karena penggunaan pestisida tergantung intensitas serangan hama penyakit, semakin tinggi serangan hama penyakit, maka pemberatasan hama penyakit yang perlu dilakukan dan mendorong penggunaan pestisida lebih banyak. Nilai koefisien regresi 0,062 menunjukkan bahwa peningkatan penggunaan pestisida sebesar $1 \%$ akan mengakibatkan produksi petani meningkat $0,062 \%$. Hal ini mengindikasikan bahwa penggunaan pestisida pada fungsi produksi berada pada daerah rasional. Dalam kondisi seperti ini petani kentang tidak selalu harus menambah pestisida karena pengendalian harus dilakukan secara effisien. Penggunaan pestisida harus sesuai dengan keadaan tanaman yang ada. Penggunaan dosis dan waktu yang tepat, akan membantu meningkatkan hasil produksi. Selain itu, pengunaan pestisida yang berlebihan juga akan menyebabkan tidak efisiensinya biaya yang akan dikeluarkan nantinya.

Tenaga kerja berpengaruh positif terhadap produksi dan secara statistik signifikan pada taraf uji 1\%. Artinya, semakin besar tenaga kerja yang digunakan petani, semakin tinggi produksi yang diperoleh namun pertambahannya sedikit. Hal ini nampak pada nilai koefisien regresi sebesar 0,157 faktor produksi tenaga kerja. Hal ini berarti tenaga kerja berada pada daerah yang rasional. Artinya, apabila petani menambah tenaga kerja sebesar $1 \%$ maka produksi kentang akan meningkat sebesar $0,157 \%$. Dummy varietas berpengaruh nyata secara statistik signifikan pada taraf uji $1 \%$, yang artinya ada perbedaan antara produksi kentang atlantik dan kentang granola. Produksi kentang atlantik di Kecamatan Sempol lebih tinggi dibanding kentang granola hal ini dapat dilihat dari nilai constanta persamaan regresi. Constanta persamaan produksi kentang atlantik sebesar 6,437 sedang kentang granola 5,807 yang berarti produksi kentang atlantik lebih besar 1,10 
kali lipat dibanding kentang granola.

Besarnya produksi kentang atlantik tetapi produktivitas yang lebih rendah berdasarkan hadis analisis produkivitas, lebih besarnya produksi kentang atlantik dibanding kentang granola disesabkan luas tanamn yang lebih besar bukan karena produktivitas yang lebih tinggi. Hal inilah yang perlu disadari oleh petani sehingga tidak terus menjalin kemitraan dengan PT Indofood.

\section{KESIMPULAN}

Berdasarkan

perumusan

masalah, tujuan penelitian hipotesis dan hasil penelitian serta pembahasan, maka dapat di simpulkan : (1) Ada perbedaan biaya produksi antara usahatani kentang atlantik dan kentang granola namun secara statistik tidak berbeda nyata pada taraf kepercayaan 90\%. Biaya produksi kentang granola lebih tinggi yaitu sebesar Rp 22.500.279 sedang kentang atlantik lebih rendah yang sebesar $\mathrm{Rp}$ $22.146 .941 ; \quad$ (2) Ada perbedaan produktivitas lahan antara usahatani kentang, namun secara statistik tidak signifikan pada taraf kerpcayaan $90 \%$. Produktivitas lahan kentang atlantik lebih rendah yaitu sebesar $9.462 \mathrm{~kg} / \mathrm{ha}$ dibandingkan dengan kentang granola yang sabesar $9.666 \mathrm{~kg} / \mathrm{ha}$. Ada perbedaan produktivitas tenaga kerja antar usahatani kentang dan secara statistik berbeda nyata pada taraf kepercayaan $90 \%$. Produktivitas tenaga kerja kentang atlantik lebih tinggi yaitu sebesar 73,00 kg/JHK dibanding dengan kentang granola yang sebesar 59,34 kg/JHK; (3) Ada perbedaan keuntungan antara usahatani kentang atlantik dan kentang granola, secara statistik berbeda nyata pada taraf kepercayaan 99\%. Keuntungan usahatani kentang granola lebih tinggi yaitu sebesar Rp37.027.999/ha dibandingkan kentang atlantik yang sebesar Rp15.700.553/ha; (4) Faktorfaktor yang berpengaruh dan signifikan terhadap produksi usahatani kentang adalah bibit, pupuk, tenaga kerja dan varietas, sedangkan faktor luas lahan dan pestisida berpengaruh positif tetapi secara statistik tidak signifikan terhadap produksi usahatani kentang di Kecamatan Sempol, Kabupaten Bondowoso.

\section{DAFTAR PUSTAKA}

Anggriawan AU. 2011. Efisiensi teknis Usahatani Kentang dan Faktor yang Mempengaruhi di Kecamatan Banjarnegara \{Skripsi\}. Bogor.

\section{Ashandi A. A. 1995. Meningkatkan}

Produksi Kentang. Balai Penelitian Hortikultura Lembang. Jakarta: Departemen Pertanian. 
BPS Indonesia. 2015. Indonesia Dalam Angka. Badan Pusat Statistik Indonesia. Indonesia.

BPS Kabupaten Bondowoso, 2016. Kabupaten Bondowoso Dalam Angka Tahun 2017. Bondowoso.

Samadi, B, Ir. 2007. Kentang dan Analisis Usahatani Edisi Revisi. Kanisius: Hortikultura. Pusat Analisis Sosial Ekonomi dan Kebijakan Pertanian.

Sihombing, L. 2005. Analisis

Tataniaga Kentang di Propinsi Sumatera Utara. Kultura 40:2.

Singarimbun, M. 1985. Metode Penelitian Survei. Jakarta: P3ES.

Soekartawi, Soeharjo A, Dillon JL, Hardaker JB. 1986. Ilmu Usahatani dan Penelitian untuk Pengembangan Petani Kecil UI-Press. Jakarta.
Sutiarso. 2010. Analisis Regresi Sederhana, Program Studi Agribisnis, Fakultas Pertanian. Universitas Muhammadiyah Jember. Jember

Supranto, J 2009. Statistik Teori dan Aplikasi, Edisi Ketijuh Jilid 2. Jakarta: Erlangga.

Wattimenna G. A . 2000. Pengembangan Propagol Kentang Bermutu dan Kultivar Kentag unggul dalam Mendukung Peningkatan Produksi Kentang di Indonesia. Orasi Ilmiah Guru Besar Tetap Hortikultura. Fakultas Pertanian. Bogor. 